\title{
Influence of Annealing Treatments on Microstructure and Mechanical Properties of an Extruded Mg AZ31/Al 7050 Laminate
}

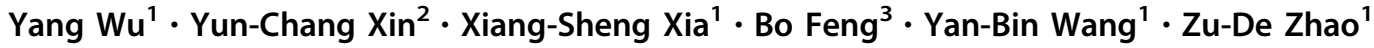

Received: 6 June 2018/Revised: 16 July 2018/Published online: 28 August 2018

(C) The Chinese Society for Metals and Springer-Verlag GmbH Germany, part of Springer Nature 2018

\begin{abstract}
Mg AZ31/Al 7050 laminate was fabricated by co-extrusion directly from the as-cast Mg AZ31 and Al 7050 billets. The influence of annealing temperature and annealing time on microstructure and mechanical behavior of the extruded $\mathrm{Mg} / \mathrm{Al}$ laminate was systematically studied. Results show that annealing treatments at $250{ }^{\circ} \mathrm{C}$ for $3 \mathrm{~h}$ or at $350{ }^{\circ} \mathrm{C}$ for $3 \mathrm{~h}$ do not result in an obvious grain coarsening of $\mathrm{Mg}$ layer and cannot remove the heterogeneous structure. Annealing does not vary texture in the Mg layer, a large fraction of $<0002>/ / \mathrm{ND}$ and a small fraction of $<0002>/ / \mathrm{TD}$, but the intensity of component $<0002>/ / \mathrm{ND}$ weakens to some extent. Lamellar microstructure in the Al layer remains after annealing at $250{ }^{\circ} \mathrm{C}$ for $3 \mathrm{~h}$ or at $350{ }^{\circ} \mathrm{C}$ for $3 \mathrm{~h}$. High fractions of the texture components $\mathrm{S}$ and cube exist in the extruded sample, and annealing treatment hardly changes their fractions. Post-annealing treatment will largely reduce yield strength of extruded plate and increase plasticity slightly. The yield strength drops from $302 \mathrm{MPa}$ to $206 \mathrm{MPa}$ after annealing at $250{ }^{\circ} \mathrm{C}$ for $3 \mathrm{~h}$ and to $141 \mathrm{MPa}$ after annealing at $350{ }^{\circ} \mathrm{C}$ for $3 \mathrm{~h}$. The elongation to fracture increases from $1.5 \%$ to $5.4 \%$ after annealing at $250{ }^{\circ} \mathrm{C}$ for $3 \mathrm{~h}$ and to $4.8 \%$ at $350{ }^{\circ} \mathrm{C}$ for $3 \mathrm{~h}$. The corresponding mechanism was discussed.
\end{abstract}

Keywords Laminate composite $\cdot$ Annealing $\cdot$ Microstructure $\cdot$ Texture $\cdot$ Mechanical property

\section{Introduction}

Magnesium alloy is a desirable candidate as important structural materials for weight saving in the automotive and aerospace industries [1-5]. However, compared to its counterpart aluminum alloys, the applications of Mg alloys have been greatly limited by their low strength and poor formability [6, 7]. Hybrid metal composites fabricated from different metals are effective to improve mechanical properties such as strength, ductility, impacting performance, fatigue and fracture $[5,6,8,9]$. A Mg/Al multilayer

Available online at http://link.springer.com/journal/40195

Yun-Chang Xin

ycxin@cqu.edu.cn

1 Southwest Technology and Engineering Research Institute, Chongqing 400039, China

2 International Joint Laboratory for Light Alloys, College of Materials Science and Engineering, Chongqing University, Chongqing 400030, China

3 Guangdong Institute of Materials and Processing, Guangdong Academy of Sciences, Guangzhou 510650, China laminate combing the advantages of $\mathrm{Mg}$ and $\mathrm{Al}$ alloys has provoked much interest in the fields of automobile and aerospace in quest of excellent impacting or damping capacities [10-12]. The most widely used method to fabricate $\mathrm{Mg} / \mathrm{Al}$ bimetal laminates is roll bonding [13-16]. However, the poor rolling ability of Mg alloys leads to a high cost and a low efficiency to prepare $\mathrm{Mg}$ plates for roll bonding [17]. It is well known that both $\mathrm{Mg}$ and $\mathrm{Al}$ alloys are suitable for extrusion. For co-extrusion of $\mathrm{Mg} / \mathrm{Al}$ laminates, as-cast billets can be used. From this point, extrusion process provides a high efficient and mass-production method [18].

In one of our previous publication [19], a Mg AZ31/Al 7050 laminate was successfully fabricated by co-extrusion. The results show that this $\mathrm{Mg} / \mathrm{Al}$ laminate can harden AZ31 Mg alloy evidently without an obvious increase in the weight of constructions. Annealing is an effective way to modify the microstructure and texture of $\mathrm{Mg}$ alloys. Besides the grain size and texture, the thickness of diffusion layer plays an important role in mechanical properties of $\mathrm{Mg} / \mathrm{Al}$ laminate [16, 20, 21]. The bonding strength of the interface remained excellent in spite of the formation of reaction phases [22, 23]. However, if many $\mathrm{Mg} / \mathrm{Al}$ 
intermetallic compounds were formed in the diffusion layer, they were usually detrimental to the bonding strength and induce cracking of interface [24]. This will lead to a low ductility of $\mathrm{Mg} / \mathrm{Al}$ laminate. The composition and structure of diffusion layer is related to not only the fabrication process, but the post-annealing treatments. However, the effects of annealing treatment on the microstructure and mechanical properties of bimetal laminate after hot extrusion were not studied. In the present study, Mg AZ31/Al 7050 bimetal plate was fabricated directly from as-cast $\mathrm{Mg}$ AZ31 and Al 7050. The influence of different annealing regimes on microstructure and mechanical properties of $\mathrm{Mg} / \mathrm{Al}$ laminates was systematically studied.

\section{Experimental}

\subsection{Extrusion, Annealing and Mechanical Tests}

As-cast Mg AZ31 and Al 7050 in a homogenized condition were used for fabrication of $\mathrm{Mg} / \mathrm{Al}$ composite plate. As shown in Fig. 1, the Mg AZ31/Al 7050 laminate composite was fabricated with the $\mathrm{Mg}$ alloy as the sleeve and the $\mathrm{Al}$ alloy as the core. $\mathrm{Mg}$ AZ31 billet was machined into hollow cylinders (an outer diameter $80 \mathrm{~mm}$ and an inner $40 \mathrm{~mm}$ ), and Al 7050 cylinders with a diameter of $40 \mathrm{~mm}$ were cut, polished and filled into $\mathrm{Mg}$ AZ31 hollow cup. The $\mathrm{Mg} / \mathrm{Al}$ bimetal billet was heated to $470{ }^{\circ} \mathrm{C}$ and kept at $470{ }^{\circ} \mathrm{C}$ for $2 \mathrm{~h}$ and immediately extruded at $470{ }^{\circ} \mathrm{C}$. An extrusion rate of $4.5 \mathrm{~mm} / \mathrm{min}$ was used. The as-extruded AZ31/7050 laminate was immediately quenched in water after exiting the die, and a subsequent two-stage aging at $120{ }^{\circ} \mathrm{C}$ for $8 \mathrm{~h}$ and $150{ }^{\circ} \mathrm{C}$ for $9 \mathrm{~h}$ was carried out. The final extruded laminate had a width of $60 \mathrm{~mm}$ and a thickness of $3 \mathrm{~mm}$. The extruded plates were annealed at $250{ }^{\circ} \mathrm{C}$ and $350{ }^{\circ} \mathrm{C}$ for $1 \mathrm{~h}, 2 \mathrm{~h}$ and $3 \mathrm{~h}$, respectively.

Mechanical properties of components $\mathrm{Mg} \mathrm{AZ31,} \mathrm{Al}$ 7050 and AZ31/7050 laminate were tested on a Shimadzu mechanical testing system using a strain rate of $10^{-3} \mathrm{~s}^{-1}$ at room temperature. An extension meter was used to correct displacement. The specimens for tensile tests of the AZ31/ 7050 laminate (the designated $\mathrm{Mg} / \mathrm{Al}$ ), the $\mathrm{Al} 7050$ layer (the designated $\mathrm{Al}$ ) and the Mg AZ31 layer (the designated $\mathrm{Mg}$ ) were cut directly from the extruded laminate. Each mechanical test was repeated three times.

\subsection{Characterization of Microstructure and Texture}

Microstructure was examined using an optical microscope (ZEISS, Axiovert 40 MAT) and a scanning electron microscope (SEM, TESCAN Vega TS 5136XM). Element distribution in the diffusion layer was analyzed by energy dispersive X-ray spectroscopy (EDS). Electron backscattered diffraction (EBSD) examination using a step size of $1 \mu \mathrm{m}$ was performed on a FEI Nova 400 SEM equipped with a HKL Channel 5 system. Samples of EBSD mapping were mechanically ground followed by electrochemical polishing. Electrochemical polishing of $\mathrm{Mg}$ samples was in an AC2 electrolyte and Al samples in a perchloric acid solution (1 ml perchloric acid and $9 \mathrm{ml}$ ethanol) at $20 \mathrm{~V}$. All EBSD data were analyzed using the Channel 5 software.

\section{Results}

\subsection{Microstructure}

Figure 2 shows optical microstructure of the $\mathrm{Mg}$ layer in the extruded and annealed $\mathrm{Mg} / \mathrm{Al}$ bimetal plates. As seen in Fig. 2a, the extruded laminate has an obvious gradient microstructure from surface to center. The surface contains finer grains than the center. An obvious heterogeneous structure containing both coarse grains and fine grains is seen in both the center and surface. This heterogeneous grain structure remains after different annealing treatments, and a higher annealing temperature and a longer annealing duration do not result in an obvious grain coarsening.

Cross section EDS mappings of the extruded and the annealed laminates are presented in Fig. 3. A good bonding

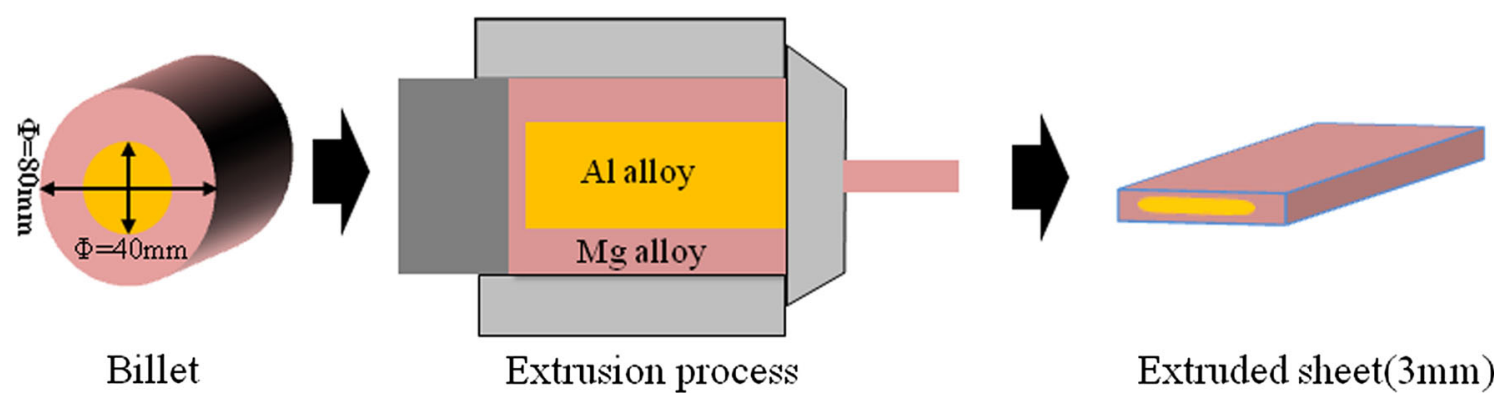

Fig. 1 A schematic diagram showing fabrication of $\mathrm{Mg} / \mathrm{Al}$ laminate composite by a co-extrusion 

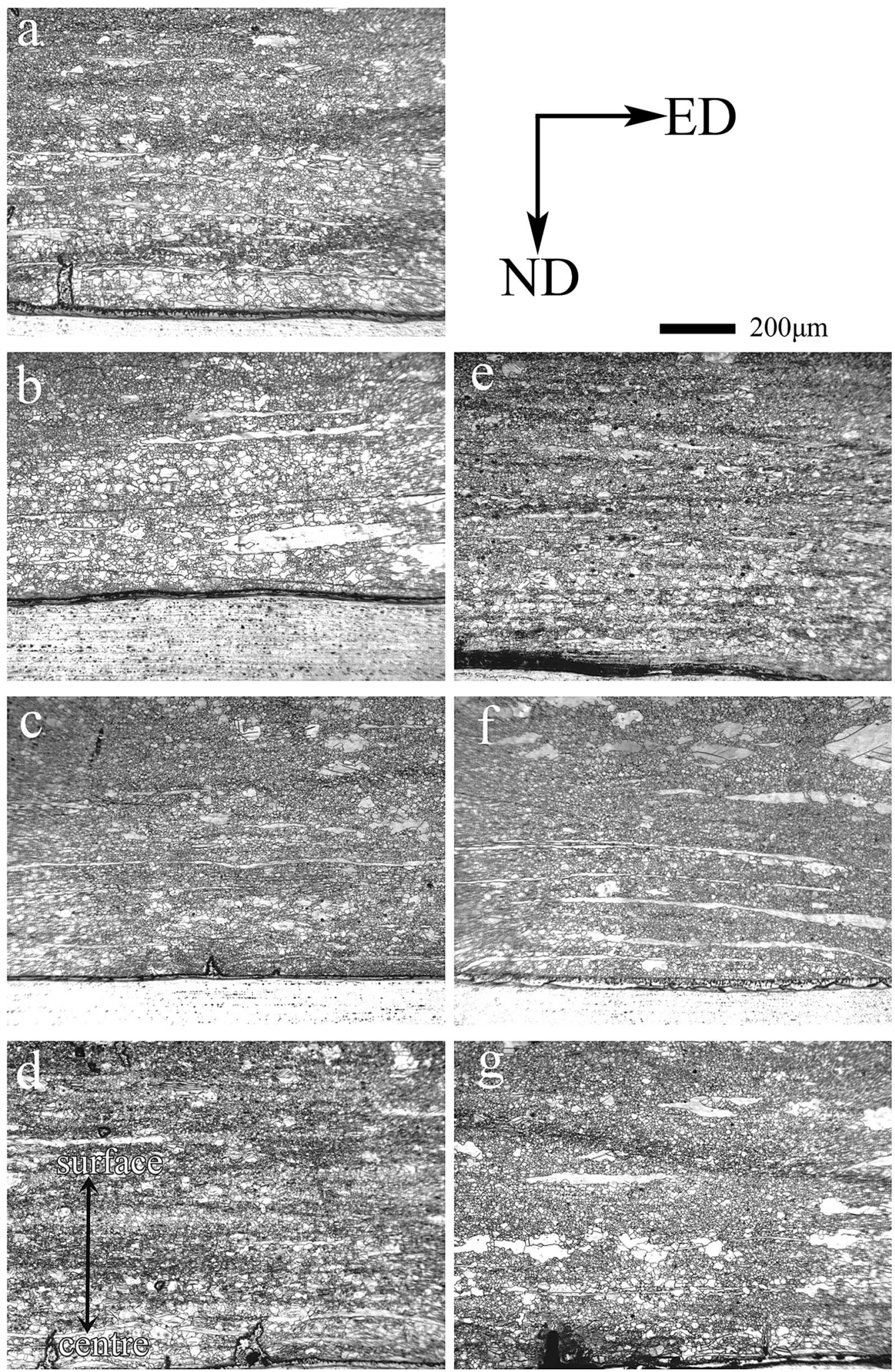

Fig. 2 Optical microstructure of the $\mathrm{Mg}$ layer in $\mathrm{Mg} / \mathrm{Al}$ laminate: a extruded; annealed at $250{ }^{\circ} \mathrm{C}$ for b $1 \mathrm{~h}$, c $2 \mathrm{~h}$, d $3 \mathrm{~h}$; annealed at $350{ }^{\circ} \mathrm{C}$ for e $1 \mathrm{~h}, \mathbf{f} 2 \mathrm{~h}, \mathbf{g} 3 \mathrm{~h}$. ND and ED refer to the normal direction and extrusion direction of the plate, respectively 


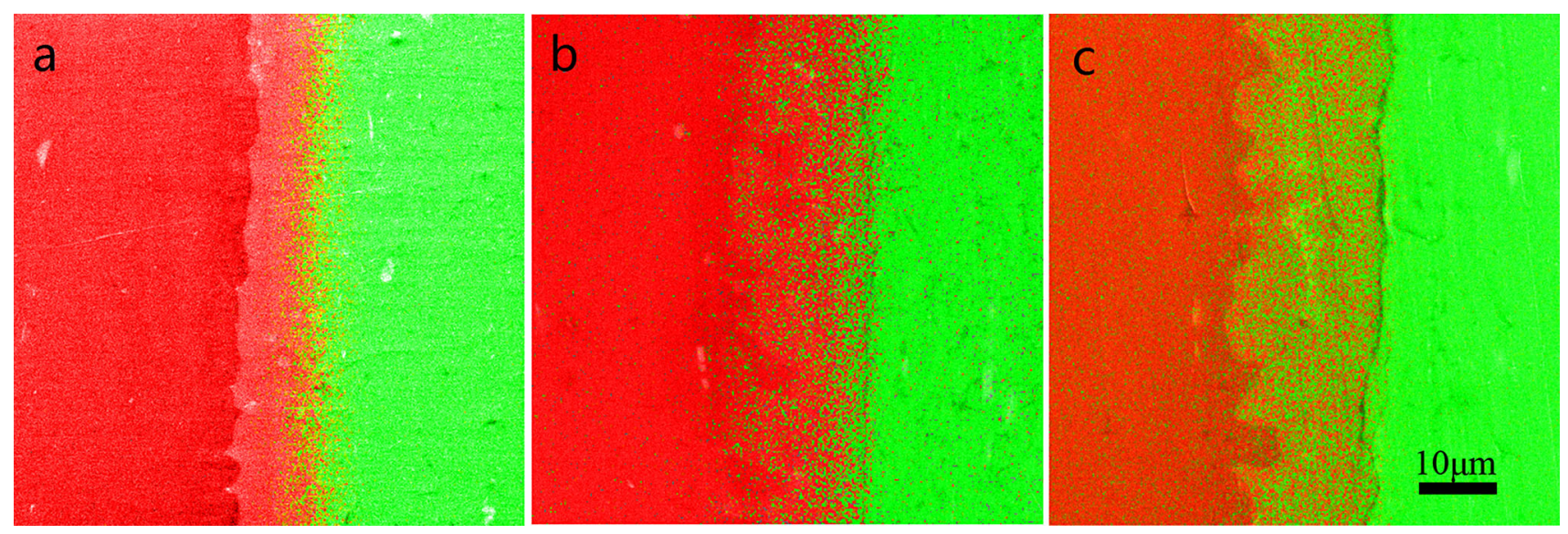

Fig. 3 Cross section EDS mapping of Mg/Al laminate: a as-extruded, b annealed at $250{ }^{\circ} \mathrm{C}$ for $3 \mathrm{~h}$, $\mathbf{c}$ annealed at $350{ }^{\circ} \mathrm{C}$ for $3 \mathrm{~h}$ (points in red and green represent elements $\mathrm{Mg}$ and $\mathrm{Al}$, respectively)

is observed between the $\mathrm{Mg}$ layer and $\mathrm{Al}$ layer. The thickness of transition layer in the extruded plate is about $10 \mu \mathrm{m}$. EDS mapping shows that the diffusion layer contains two distinct sub-layers. This double-layered structure is often seen in the transition layers of $\mathrm{Mg} / \mathrm{Al}$ composites [25]. It is reported that the sub-layer adjacent to $\mathrm{Mg}$ often contains $\mathrm{Mg}_{17} \mathrm{Al}_{12}$, and that next to the $\mathrm{Al}$ consists of a high fraction of $\mathrm{Mg}_{2} \mathrm{Al}_{3}$ [26]. After annealing, the diffusion layer thickens and the thickness is about $20 \mu \mathrm{m}$ after annealing and the double-layered structure disappears.

\subsection{Texture}

The inverse pole figure maps and pole figures of $\mathrm{Mg}$ sleeve in $\mathrm{Mg} / \mathrm{Al}$ laminates after different annealing treatments are presented in Fig. 4. There are two texture components in the $\mathrm{Mg}$ layer, a high fraction of component $<0002>/ / \mathrm{ND}$ and a low fraction of component $<0002>/ / T D$. An obvious preferred distribution of prismatic planes $(<10-10>/ / \mathrm{ED})$ is also seen. Here, TD and ND refer to the transverse direction and normal direction of the plate, respectively. After annealing at $250{ }^{\circ} \mathrm{C}$ for $3 \mathrm{~h}$ or at $350{ }^{\circ} \mathrm{C}$ for $3 \mathrm{~h}$, both the two texture components remain. There is also a
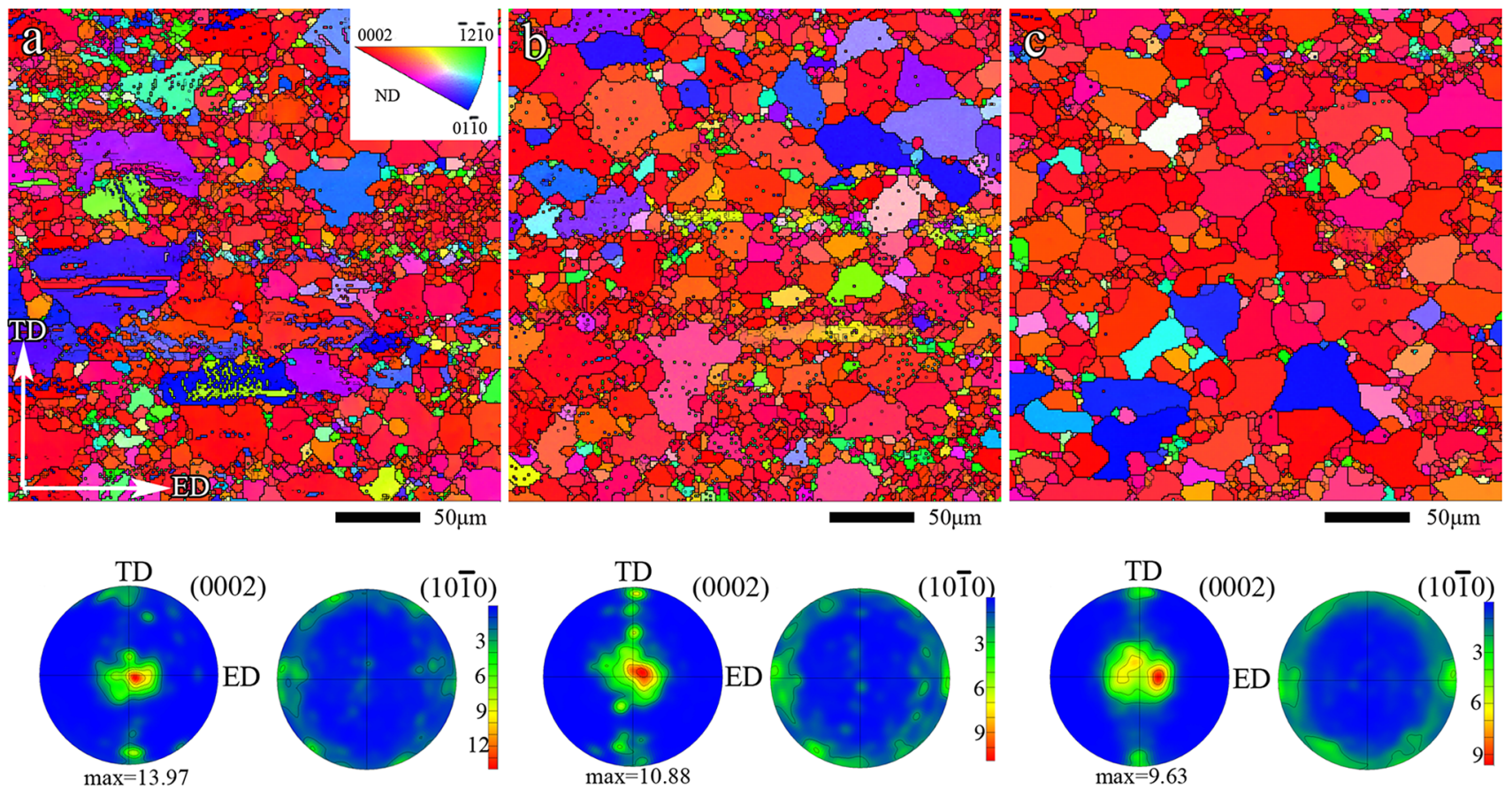

Fig. 4 Inverse pole figure maps and pole figures of $\mathrm{Mg}$ layer in the $\mathrm{Mg} / \mathrm{Al}$ laminate: a extruded laminate, $\mathbf{b}$ annealing at $250{ }^{\circ} \mathrm{C}$ for $3 \mathrm{~h}$, c annealing at $350{ }^{\circ} \mathrm{C}$ for $3 \mathrm{~h}$ 

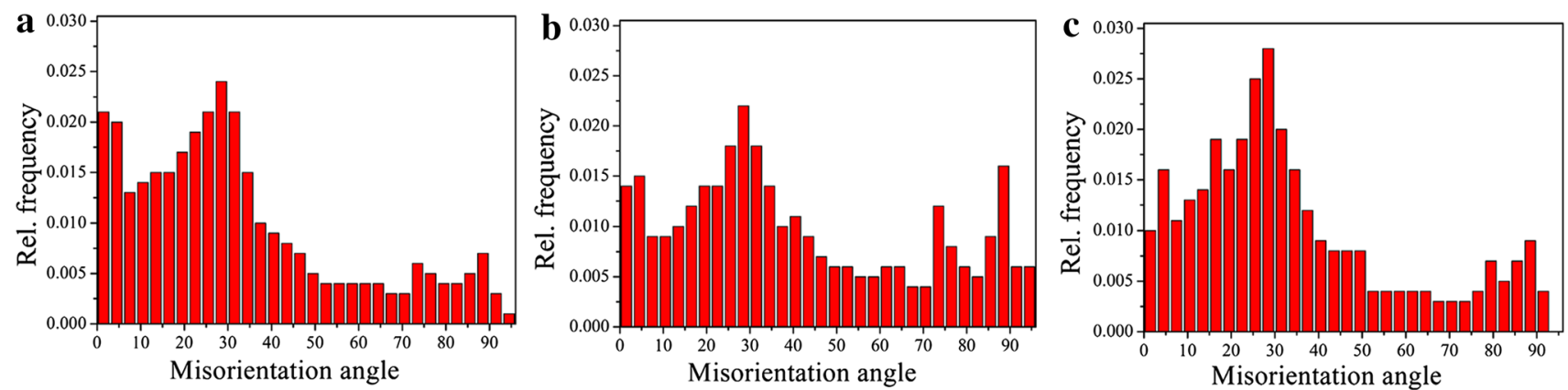

Fig. 5 Misorientation angle distributions in the Mg layer: a extruded laminate, $\mathbf{b}$ annealing at $250{ }^{\circ} \mathrm{C}$ for $3 \mathrm{~h}$, $\mathbf{c}$ annealing at $350{ }^{\circ} \mathrm{C}$ for $3 \mathrm{~h}$

preferred distribution of prismatic planes in the annealed samples. There is an obvious peak around $30^{\circ}$ in the misorientation angles shown in Fig. 5. This is ascribed to a high fraction of recrystallized grains. Annealing reduces the fraction of the low angle boundaries below $4^{\circ}$, which generally corresponds to the deformed structure.

Figure 6 is the inverse pole figure maps and pole figures of $\mathrm{Al}$ component after different annealing treatments. A lamella structure is seen in the as-extruded plate, and many low angle boundaries with misorientation below $10^{\circ}$ appear (see Fig. 7). Annealing hardly changes the microstructure. Generally, texture of the Al extruded product might contain several different texture components including copper, S and brass. Furthermore, cube and Goss components are also important ones. The fractions of five typical texture components, cube $\{001\}<100>$, Goss $\{011\}$
$<100>$, brass $\{011\}<211>$, S $\{123\}<634>$ and copper $\{112\}<111>$, are analyzed and displayed in Table 1 . They were calculated by integrating the ODF within $15^{\circ}$ of the ideal texture component. After annealing treatment, the texture components of $\mathrm{Al}$ core are not significantly changed. The Al core has a high fraction of S and cube texture, and components Goss, brass and copper are nearly absent.

\subsection{Mechanical Behavior}

True stress-strain curves of the extruded and the annealed $\mathrm{Mg} / \mathrm{Al}$ laminates, $\mathrm{Mg}$ sleeve and $\mathrm{Al}$ core under tension along the ED are displayed in Fig. 8 and the yield strengths, ultimate strengths and elongations to fracture are listed in Table 2. The extruded $\mathrm{Mg} / \mathrm{Al}$ composite has a yield strength of $301 \mathrm{MPa}$, but a quite low elongation,
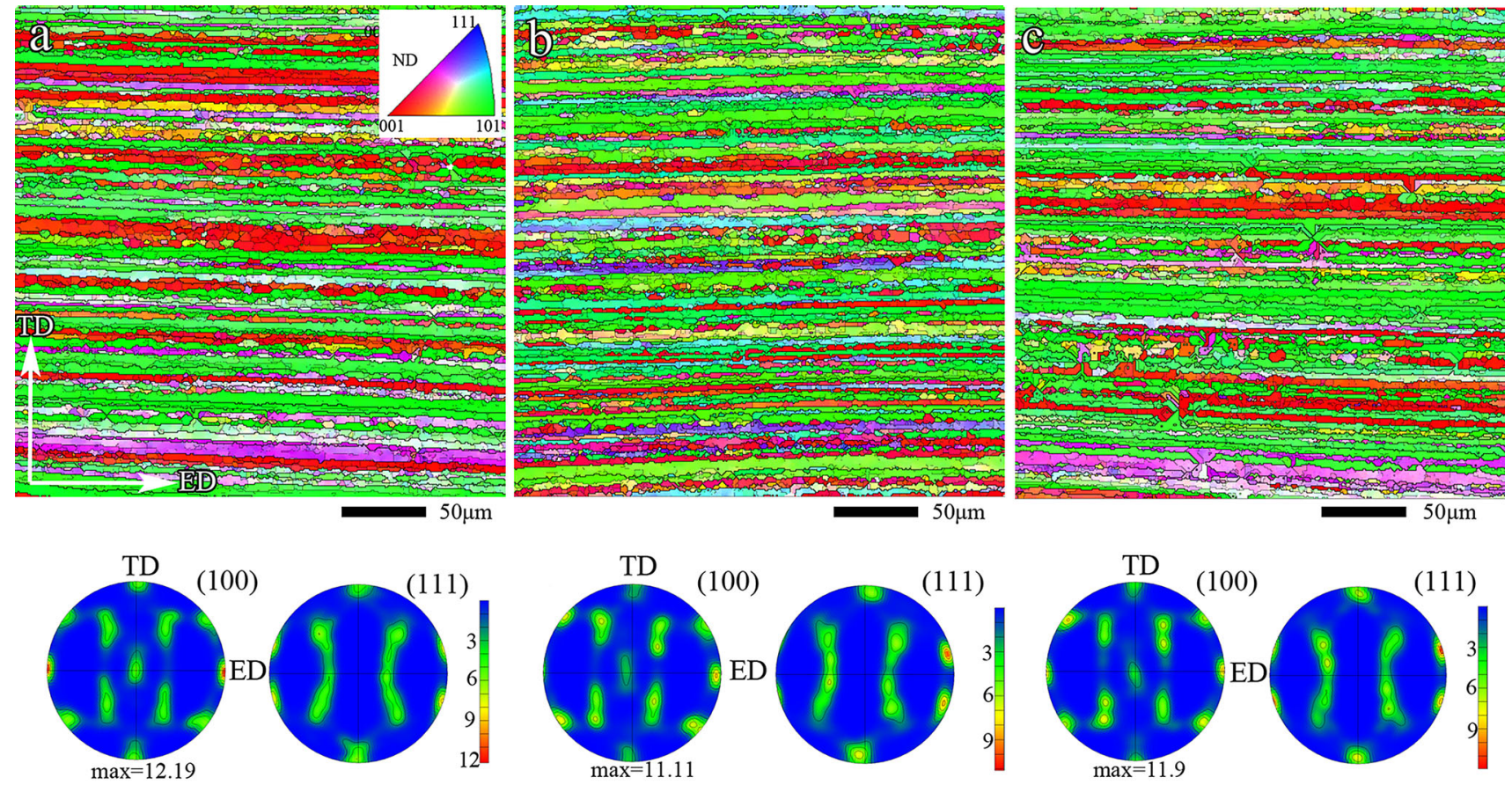

(111)

Fig. 6 Inverse pole figure map and pole figures of $\mathrm{Al}$ layer in $\mathrm{Mg} / \mathrm{Al}$ laminate: a extrusion laminate, $\mathbf{b}$ annealing at $250{ }^{\circ} \mathrm{C}$ for $3 \mathrm{~h}, \mathbf{c}$ annealing at $350{ }^{\circ} \mathrm{C}$ for $3 \mathrm{~h}$ 

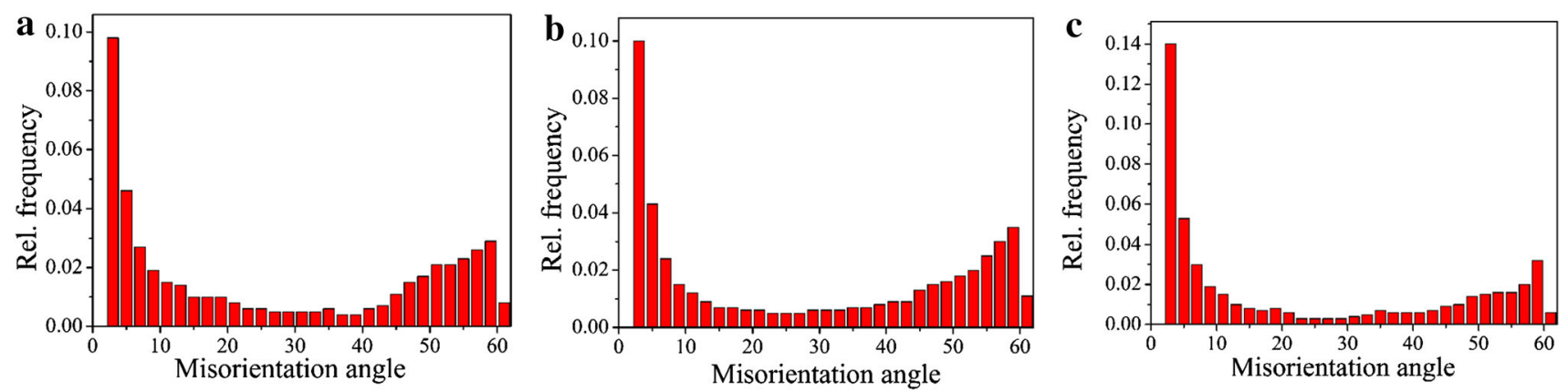

Fig. 7 Misorientation angle distributions in the Al layer: a extruded laminate, b annealing at $250{ }^{\circ} \mathrm{C}$ for $3 \mathrm{~h}$, $\mathbf{c}$ annealing at $350{ }^{\circ} \mathrm{C}$ for $3 \mathrm{~h}$

Table 1 Fractions of different texture components in the $\mathrm{Al}$ layer of the $\mathrm{Mg} / \mathrm{Al}$ laminate

\begin{tabular}{llllll}
\hline Samples & $\begin{array}{l}\text { Goss } \\
\{011\}<100>\end{array}$ & $\begin{array}{l}\text { S } \\
\{123\}<634>\end{array}$ & $\begin{array}{l}\text { Cube } \\
\{001\}<100>\end{array}$ & $\begin{array}{l}\text { Brass } \\
\{011\}<211>\end{array}$ & $\begin{array}{l}\text { Copper } \\
\{112\}<111>\end{array}$ \\
\hline Extruded sample $(\%)$ & 0 & 57.7 & 19.2 & 0 & 2.1 \\
Annealing at $250^{\circ} \mathrm{C}$ for $3 \mathrm{~h}(\%)$ & 0 & 55.5 & 19.7 & 0 & 1.8 \\
Annealing at $350^{\circ} \mathrm{C}$ for $3 \mathrm{~h}(\%)$ & 0 & 56.0 & 19.5 & 0 & 2.2 \\
\hline
\end{tabular}
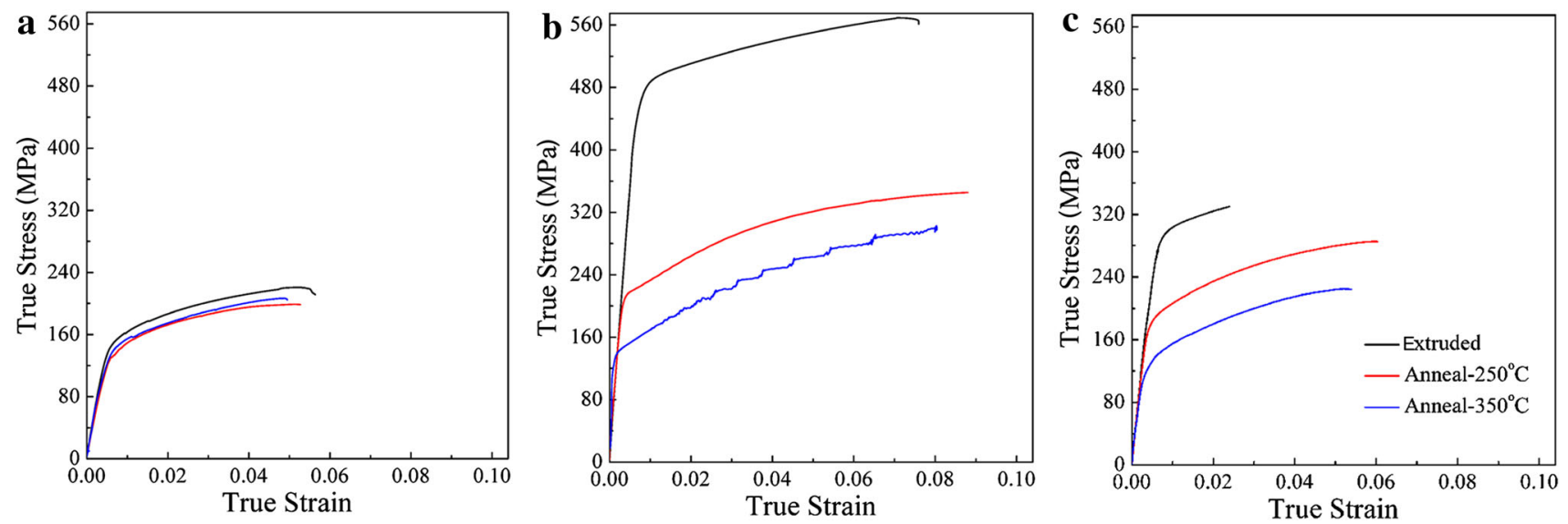

Fig. 8 True stress-strain curves under tension along the ED: a Mg layer, b Al layer, c Mg/Al laminate

Table 2 Yield strengths, ultimate strengths and elongations to fracture under tension along the ED

\begin{tabular}{lclc}
\hline Samples & Yield strength $(\mathrm{MPa})$ & Ultimate strength $(\mathrm{MPa})$ & Elongation $(\%)$ \\
\hline Extrusion laminate & & & \\
$\mathrm{Mg} / \mathrm{Al}$ & 301 & 330 & 1.5 \\
$\mathrm{Mg} / \mathrm{Al}-\mathrm{Mg}$ & 152 & 218 & 4.3 \\
$\mathrm{Mg} / \mathrm{Al}-\mathrm{Al}$ & 491 & 570 & 6.6 \\
$\mathrm{Annealing}$ at & $250{ }^{\circ} \mathrm{C}$ for $3 \mathrm{~h}$ & & 5.4 \\
$\mathrm{Mg} / \mathrm{Al}$ & 206 & 286 & 4.4 \\
$\mathrm{Mg} / \mathrm{Al}-\mathrm{Mg}$ & 147 & 199 & 8.1 \\
$\mathrm{Mg} / \mathrm{Al}-\mathrm{Al}$ & 230 & 355 & \\
$\mathrm{Annealing}$ at & $350{ }^{\circ} \mathrm{C}$ for $3 \mathrm{~h}$ & & 4.8 \\
$\mathrm{Mg} / \mathrm{Al}$ & 141 & 225 & 4.7 \\
$\mathrm{Mg} / \mathrm{Al}-\mathrm{Mg}$ & 150 & 206 & 8.0 \\
$\mathrm{Mg} / \mathrm{Al}-\mathrm{Al}$ & 144 & 301 &
\end{tabular}


$1.5 \%$. The yield strengths of $\mathrm{Mg}$ sleeve and $\mathrm{Al}$ core are $152 \mathrm{MPa}$ and $491 \mathrm{MPa}$, respectively. They both have a higher elongation than the composite. The elongation of $\mathrm{Mg} / \mathrm{Al}$ multilayer laminate is up to $5.4 \%$ after annealing at $250{ }^{\circ} \mathrm{C}$ for $3 \mathrm{~h}$ and $4.8 \%$ after annealing at $350{ }^{\circ} \mathrm{C}$ for $3 \mathrm{~h}$, but the yield strength drops to a large extent. Note that annealing treatment hardly reduces the yield strength of $\mathrm{Mg}$ sleeve, but leads to a fast drop of the Al core. Obviously, this is the main reason for the reduced yield strength of composite after annealing.

\section{Discussion}

\subsection{Microstructure and Texture of Multilayer Laminates}

Rolling bonding is the most often used method to fabricate bimetal laminates. This method exhibits a high efficiency and low cost for fabrication of multilayer plates such as $\mathrm{Al} /$ $\mathrm{Al}, \mathrm{Al} /$ steel and $\mathrm{Al} / \mathrm{Ti}$. However, the poor rolling ability of $\mathrm{Mg}$ alloys leads to a low efficiency and a high cost to fabricate $\mathrm{Mg}$ thin plates and, resultantly, results in a low efficiency to prepare $\mathrm{Mg} / \mathrm{Al}$ laminates using roll bonding. Compared to rolling, extrusion can generate an extra compressive stress state from the die [27]. This is capable of enhancing the working ability of $\mathrm{Mg}$ alloy. In addition, the use of co-extrusion can prepare thin $\mathrm{Mg} / \mathrm{Al}$ laminate directly from the as-cast billet. Therefore, $\mathrm{Mg} / \mathrm{Al}$ bimetal laminates fabricated by extrusion represents a highly efficient and mass-production method for industrial productions. During extrusion bonding, a strong friction stress and shear often exist at the layer/layer interface. This strong and complicated stress state might refine the grains in AZ31 and 7050 layers [27]. In addition, the thermal conductivity of the $\mathrm{Mg}$ sleeve AZ31 is lower than the $\mathrm{Al}$ core 7050 in the $\mathrm{Mg} / \mathrm{Al}$ multilayer plate [28]. During extrusion, the adiabatic heating is mainly conducted by the $\mathrm{Al}$ layer, which will contribute to refine the grain in the Mg layer. This is probably the reason for why there is a fine grain structure in the $\mathrm{Mg}$ layer extruded at a high temperature of $470{ }^{\circ} \mathrm{C}$. Because of the high extrusion temperature, the stored energy from the deformation of $\mathrm{Mg}$ alloy was released significantly by dynamic recovery and recrystallization during hot extrusion process.

A strong friction stress often exists at the $\mathrm{Mg}-\mathrm{Al}$ interface [29, 30]. As seen in Fig. 4, the $\mathrm{Mg}$ layer in $\mathrm{Mg} / \mathrm{Al}$ composite has a typical texture of monolithic $\mathrm{Mg}$ alloy extruded laminates, which is composed of a high fraction of component $<0002>/$ ND and a small fraction of component $<0002>/ / \mathrm{TD}$. This indicates that the complicated stress condition during co-extrusion of $\mathrm{Mg} / \mathrm{Al}$ bimetal billet cannot change the texture in $\mathrm{Mg}$ layer. After annealing treatment, the texture of $\mathrm{Mg}$ layer also contains components $<0002>/ / \mathrm{ND}$ and $<0002>/ / \mathrm{TD}$. That is, the texture of the $\mathrm{Mg}$ layer is insensitive to annealing treatments. The intensity of component $<0002>/ / \mathrm{TD}$ weakens to some extent, which will contribute to a better working capability of the Mg layer. As shown in Table 1, the Al layer has a strong $\beta$-fiber texture including a high faction of $S$ component. Generally, this strong $\beta$-fiber texture often appears in deformed $\mathrm{Al}$ and its alloys [31].

\subsection{Mechanical Behavior of Hybrid Metal Laminate}

The $\mathrm{Mg} / \mathrm{Al}$ laminate has a high yield strength, but a much low ductility. The hard Al layer effectively enhances the yield strength from 152 to $301 \mathrm{MPa}$. Generally, the brittle intermetallics between $\mathrm{Al}$ and $\mathrm{Mg}$ layers easily induce cracking at diffusion layer during loading. This interface cracking will influence the load transfer between Mg layer and $\mathrm{Al}$ layer, leading to a stress concentration or a localized deformation. According to our previous publication [16], diffusion layer cracking easily appears just after yielding during ED tension. The quick cracking at interface during ED tension is suspected to be an important reason for the low elongation of $\mathrm{Mg} / \mathrm{Al}$ laminate composite.

After annealing, the diffusion layer does not thicken to a large extent. Therefore, the decrease in deformed structure after annealing is considered to be the main reason for the increase in elongation from $1.5 \%$ before annealing to $5.4 \%$ after annealing. However, annealing at high temperatures will lead to coarsening of the strengthening phase in $\mathrm{Al}$ core [32]. This in turn reduces the yield strength of $\mathrm{Al}$ layer as well as that of the $\mathrm{Mg} / \mathrm{Al}$ composite. Therefore, to prepare a high-performance $\mathrm{Mg} / \mathrm{Al}$ laminate, it is important to acquire a fully recrystallized structure after extrusion. A post-annealing treatment is not suitable for $\mathrm{Mg} / \mathrm{Al}$ laminate containing precipitate hardening phases.

For a composite, the relationship between the average density of a composite and the density of each component can be calculated by the rule of mixture [33]:

$\rho_{\mathrm{c}}=\rho_{1} * V_{1}+\rho_{2} * V_{2}$

where $\rho_{\mathrm{c}}$ is density of $\mathrm{Mg} / \mathrm{Al}$ composite, $\rho_{i}$ and $V_{i}$ are the density and volume fraction of component " $i$ ", respectively. The hard $\mathrm{Al}$ core has a volume fraction of $40 \%$ in the specimens for tension. The densities of $\mathrm{Al}$ alloy and $\mathrm{Mg}$ alloy are $2.7 \mathrm{~g} / \mathrm{cm}^{3}$ and $1.8 \mathrm{~g} / \mathrm{cm}^{3}$, respectively. Therefore, the density of $\mathrm{Mg} / \mathrm{Al}$ laminate is about $2.16 \mathrm{~g} / \mathrm{cm}^{3}$, calculated by Eq. (1). Compared to Mg AZ31 layer, the weight of extruded $\mathrm{Mg} / \mathrm{Al}$ laminate only increases by $20 \%$, but the yield strength doubles. This indicates that a hard $\mathrm{Al}$ layer is an effective way to harden $\mathrm{Mg}$ products. 


\section{Conclusions}

In the present study, a Mg AZ31/Al 7050 laminate was fabricated by extrusion directly from the as-cast Mg AZ31 and $\mathrm{Al} 7050$ billets. The influence of annealing temperature and annealing time on microstructure and mechanical behavior of the extruded $\mathrm{Mg} / \mathrm{Al}$ laminate was systematically studied. Several conclusions are reached as follows:

(1) Annealing at $250{ }^{\circ} \mathrm{C}$ for $3 \mathrm{~h}$ or at $350{ }^{\circ} \mathrm{C}$ for $3 \mathrm{~h}$ does not induce an obvious grain coarsening of $\mathrm{Mg}$ layer and cannot remove the heterogeneous structure, too. Annealing treatment does not change the type of texture in the $\mathrm{Mg}$ layer, a large fraction of $<0002>/$ /ND and a small fraction of $<0002>/ / T D$, but weakens the intensity of component $<0002>/ /$ ND.

(2) The lamellar microstructure in the $\mathrm{Al}$ layer remains after annealing at $250{ }^{\circ} \mathrm{C}$ for $3 \mathrm{~h}$ or at $350{ }^{\circ} \mathrm{C}$ for $3 \mathrm{~h}$. There are high fractions of components $\mathrm{S}$ and cube in the extruded sample, and annealing treatments hardly change the texture.

(3) Post-annealing treatment will largely reduce the yield strength of extruded plate and increase the plasticity slightly. The yield strength drops from $302 \mathrm{MPa}$ to $206 \mathrm{MPa}$ after annealing at $250{ }^{\circ} \mathrm{C}$ for $3 \mathrm{~h}$ and to $141 \mathrm{MPa}$ after annealing at $350{ }^{\circ} \mathrm{C}$ for $3 \mathrm{~h}$. The elongation to fracture increases from $1.5 \%$ to 5.4 after annealing at $250{ }^{\circ} \mathrm{C}$ for $3 \mathrm{~h}$ and to $4.8 \%$ at $350{ }^{\circ} \mathrm{C}$ for $3 \mathrm{~h}$.

Acknowledgements This work was supported by the Fundamental Research Funds for the Central Universities (106112016CDJXZ138804) and the "111" Project (B16007) by the Ministry of Education and the State Administration of Foreign Experts Affairs of China.

\section{References}

[1] X.J. Wang, D.K. Xu, R.Z. Wu, X.B. Chen, Q.M. Peng, L. Jin, Y.C. Xin, Z.Q. Zhang, Y. Liu, X.H. Chen, G. Chen, K.K. Deng, H.Y. Wang, J. Mater. Sci. Technol. 34, 245 (2018)

[2] R. Wu, Y. Yan, G. Wang, L.E. Murr, W. Han, Z. Zhang, M. Zhang, Int. Mater. Rev. 65, 60 (2015)

[3] H.P. Zheng, J.L. Yang, R.Z. Wu, T.Z. Wang, X.D. Ma, L.G. Hou, M.L. Zhang, S. Betsofen, B. Krit, Adv. Eng. Mater. 1792, 18 (2016)
[4] T.L. Zhang, T. Tokunaga, M. Ohno, Acta Metall. Sin. (Engl. Lett.) (2018). https://doi.org/10.1007/s40195-018-0774-9

[5] T. Tokunaga, K. Matsuura, M. Ohno, J. Alloys Compd. 601, 179 (2014)

[6] H.H. Yu, Y.C. Xin, M.Y. Wang, Q. Liu, J. Mater. Sci. Technol. 34, 248 (2018)

[7] A. Macwan, X.Q. Jiang, C. Li, D.L. Chen, Mater. Sci. Eng. A 587, 344 (2013)

[8] M. Engelhardt, N. Grittner, H.S. Haverkamp, W. Reimche, D. Bormann, F.W. Bach, J. Mater. Process. Technol. 212, 1030 (2012)

[9] Y. Saito, H. Utsunomiya, N. Tsuji, T. Sakai, Acta Mater. 47, 579 (1999)

[10] Y.C. Xin, R. Hong, B. Feng, H.H. Yu, Y. Wu, Q. Liu, Mater. Sci. Eng. A 640, 210 (2015)

[11] C.Y. Liu, R. Jing, Q. Wang, B. Zhang, Y.Z. Jia, M.Z. Ma, R.P. Liu, Mater. Sci. Eng. A 558, 510 (2012)

[12] H.H. Yu, C.Z. Li, Y.C. Xin, A. Chapuis, X.X. Huang, Q. Liu, Acta Mater. 128, 313 (2017)

[13] C. Luo, W. Liang, Z. Chen, J. Zhang, C. Chi, F. Yang, Mater. Charact. 84, 34 (2013)

[14] K. Wu, H. Chang, E. Maawad, W.M. Gan, H.G. Brokmeier, M.Y. Zheng, Mater. Sci. Eng., A 527, 3073 (2010)

[15] H. Chang, M.Y. Zheng, W.M. Gan, K. Wu, E. Maawad, H.G. Brokmeier, Scr. Mater. 61, 717 (2009)

[16] X.P. Zhang, T.H. Yang, S. Castagne, J.T. Wang, Mater. Sci. Eng. A 528, 1954 (2011)

[17] C.Y. Liu, R. Jing, Q. Wang, B. Zhang, Y.Z. Jia, M.Z. Ma, R.P. Liu, Mater. Sci. Eng. A 558, 510 (2012)

[18] B. Feng, Y.C. Xin, F.L. Guo, H.H. Yu, Y. Wu, Q. Liu, Acta Mater. 120, 379 (2016)

[19] Y. Wu, B. Feng, Y.C. Xin, R. Hong, H.H. Yu, Q. Liu, Mater. Sci. Eng. A 640, 454 (2015)

[20] X.B. Liu, R.S. Chen, E.H. Han, J. Mater. Process. Technol. 209, 4675 (2009)

[21] P. He, X. Yue, J.H. Zhang, Mater. Sci. Eng. A 586, 171 (2008)

[22] H. Matsumoto, S. Watanabe, S. Hanada, J. Mater. Process. Technol. 169, 9 (2005)

[23] Y.J. Li, P. Liu, J. Wang, H.J. Ma, Vacuum 82, 15 (2007)

[24] L.M. Zhao, Z.D. Zhang, Scr. Mater. 58, 283 (2008)

[25] M. Paramsothy, M. Gupta, N. Srikanth, J. Compos. Mater. 42, 1297 (2008)

[26] M. Negendank, S. Mueller, W. Reimers, J. Mater. Process. Technol. 212, 1954 (2012)

[27] F. Pérocheau, J.H. Driver, Int. J. Plast 16, 73 (2000)

[28] J.C. Williams, E.A. Starke Jr., Acta Mater. 51, 5775 (2003)

[29] S. Gall, R.S. Coelho, S. Müller, W. Reimers, Mater. Sci. Eng. A 579, 180 (2013)

[30] C. Luo, W. Liang, Z. Chen, J. Zhang, C. Chi, F. Yang, Mater. Charact. 84, 34 (2013)

[31] J. Hirsch, T. Al-Samman, Acta Mater. 61, 818 (2013)

[32] L. Zheng, C. Liu, Y.C. Wan, P.W. Yang, X. Shu, J. Alloys Compd. 509, 8832 (2011)

[33] R. Hawkins, J.C. Wright, Int. J. Mech. Sci. 14, 875 (1972) 